\title{
Anti-inflammatory effect of non-thermal atmospheric pressure plasma for periodontitis treatment: in vitro pilot study
}

\author{
You li Park', Hyun-Joo Kim', Ju-Youn Lee1, Sung-Hee Jeong², Eun-Young Kwon, Ji-Young Joo ${ }^{1 *}$ \\ 'Department of Periodontology, ${ }^{2}$ Department of Oral Medicine, School of Dentistry and Dental Research Institute, \\ Pusan National University, Yangsan, Republic of Korea \\ ${ }^{3}$ Dental Clinic Center, Pusan National University Hospital, Busan, Republic of Korea
}

Purpose: The purpose of this study was to evaluate the anti-inflammatory effects of non-thermal atmospheric pressure plasma (NTP) on human gingival fibroblasts (HGFs) for clinical application of periodontal treatment. Materials and Methods: HGFs were treated with Porphyromonas gingivalis (Pg) lipopolysaccharide (LPS). Customized NTP device was developed for periodontal in vitro study. Cell viability was evaluated with cell counting kit-8. The levels of inflammatory cytokines, including interleukin (IL)-8 and 6, were determined by enzyme-linked immunosorbent assay. Results: When NTP was applied, the cell viability did not change significantly, and there was no difference for $6 \mathrm{~h}$ and 24h. When Pg LPS was treated to HGFs, the secretion of IL-8 and IL-6 was increased compared to the control group. But when the NTP was applied, the secretion of them was significantly decreased. Conclusion: NTP did not affect cell viability of HGFs. And it inhibited the LPS-induced production of IL-8 and IL-6. (J Dent Rehabil Appl Sci 2021;37(2):8894)

Key words: periodontitis; non-thermal atmospheric pressure plasma; pilot study; anti-inflammatory; human gingival fibroblast

\begin{abstract}
서론
물리학 또는 전기학에서 일컬어지는 플라즈마는 기체 에 강한 에너지를 공급해서 생겨난 새로운 형태의 물질 상태로서 제 4 의 물질상태를 말한다. 이는 전기적인 방 전으로 인해 생기는 전하를 땐 양이온과 전자들의 집단 으로서 이온화된 기체상태라고 볼 수 있다. ${ }^{1}$ 20세기 말부 터 플라즈마는 산업의 여러 분야에서 응용되어 왔다. 그 예로 네온사인, 형광등, 자동차 표면처리, 반도체 공정, plasma display panel 텔레비전 등으로 많은 분야에서 필 수적으로 플라즈마가 이용되고 있다. ${ }^{2}$

또한 최근에는 살균효과와 상처치유효능이 입증되면 서 의학 분야에서 임상 적용을 위한 시도들이 이어지고
\end{abstract}

*Correspondence to: Ji-Young Joo

Associate Professor, Department of Periodontology, School of Dentistry, Pusan

National University, Dental Research Institute, 20 Geumo-ro, Beomeo-ri,

Mulgeum-eup, Yangsan, 50612, Republic of Korea

Tel:+82-55-360-5203, Fax: 82-55-360-5194, E-mail: joojy@pusan.ac.kr

Received: March 11, 2021/Last Revision: April 6, 2021/Accepted: May 21, 2021
있다. ${ }^{1}$ 네덜란드의 Eva Stoffels가 주사기 형태의 플라즈 마를 이용하여 암세포를 포함한 다양한 포유세포와 미 생물에서 플라즈마에 의한 사멸효과를 보고한 이후, 살 균, 암세포사멸, 지혈, 상처치유에서 매우 주목할 만한 연 구 결과들을 바탕으로 플라즈마 메디신이라는 학문 분 야가 형성되었다. ${ }^{3}$

최근에는 불소와 함께 플라즈마를 치아절편에 처리하여 에나멜에 불소 유지력이 증가됨을 확인하거나, ${ }^{4}$ 치아미백 에 적용, ${ }^{5}$ 오염된 근관내 감염을 소독하기 위한 시도, ${ }^{6,7}$ 구 강암 치료에 적용하려는 시도 ${ }^{8}$ 등 다양한 치과영역에 플라 즈마를 적용하기 위한 연구들이 이루어지고 있다.

치주염이란 미생물 집단에 의해 야기된 치아 주변조직 의 염증성 반응으로 치주조직의 점진적인 비가역적 파괴

CopyrightC 2021 The Korean Academy of Stomatognathic Function and Occlusion. (c) It is identical to Creative Commons Non-Commercial License. 
를 초래하는 질환으로서 치아 상실을 야기하는 대표적 인 질환이다. ${ }^{9}$ 치주염의 개시는 세균의 치면 침착에서 시 작되지만 질병의 진행에는 숙주의 염증성 반응과 면역력 이 중요한 요인이 된다. 치주염을 유발하는 세균이 치면 에 많이 부착되어 있다 하더라도 숙주의 염증성 반응이 심하지 않으면 치은염 상태에 머물러 비가역적 치주조직 소실을 야기하지 않는다. ${ }^{10}$ 그러므로 치주염 치료에 효과 가 있는지 평가하기 위해서는 치주조직의 염증 반응이 잘 억제되는지가 중요한 요소이다. 실험실 평가시에는 특히 Interleukin (IL)과 같은 염증성 사이토카인의 분비를 확 인해봄으로써 염증 반응 정도를 확인해 볼 수 있다. ${ }^{11}$

치주염의 치료는 주로 기계적인 치석제거를 통해 이루 어지지만, 비외과적 처치는 치주낭내 또는 치은연하부위 의 완전한 시야확보가 되지 않을 뿐만 아니라 세균잔사 및 그 외 염증성 육아조직 등의 완벽한 제거에 한계를 가 진다. ${ }^{12}$ 이러한 술식의 한계를 극복하기 위하여 치과용레 이져, 공기분말연마기구, 소독제와 같은 보조적 요법에 관한 연구가 끊임없이 이어지고 있다. ${ }^{13,14}$ 저온상압 플라 즈마(Nonthermal atmospheric pressure plasma, NTP) 는 플라즈마의 온도가 인체와 유사한 $37^{\circ} \mathrm{C}$ 을 유지하기 때문에, 치아와 치주조직에 열손상을 일으키지 않는다고 알려져 있어 치과 치료시 적용했을때 장점을 가진다. 또 한 치주질환 원인균인 Porphyromonas gingivalis $(\mathrm{Pg})$ 의 사 멸에 있어서도 매우 효과적임이 최근에 증명되었다. ${ }^{15}$ 그 러나 플라즈마에 의한 치주염의 항염효과에 대한 연구는 거의 이루어지지 않았다. 본 연구는 인간치은섬유모세포 에서 NTP 장치가 항염증 효과를 나타내는지 평가해보 기 위한 예비실험을 진행해 보고자 한다.

\section{연구 재료 및 방법}

\section{세포배양}

본 연구는 2019년 12월에 부산대학교 치과병원 치주과 를 방문한 성인 환자의 건강한 치주조직에서 채득한 인 간치은섬유모세포를 배양하였다. 자발적으로 연구에 참 여하고자 하는 환자에 한하여 조직을 채득하였으며 임상 실험 protocol은 부산대학교 치과병원 생명윤리심의위원 회의 승인(PNUDH-2019-031)을 받았다. 채득된 치은조 직은 10\% inactivated-FBS와 1\% 항생제가 포함된 Dulbeco's Modified Eagle's Media (Gibco, Rockville, USA) 를 배지로 이용하여 $37^{\circ} \mathrm{C}$ 온도에서 $5 \% \mathrm{CO}_{2}$ 가 공급되는 습기가 있는 배양기에서 배양하였다. 배지는 통상적으로 이틀에 한번씩 새로운 것으로 교체해주었고, 계대를 하 여 세포를 증식시킨 이후 4- 6 passage에 해당하는 세포 가 실험용 플레이트에 대략 $70 \%$ 정도를 채우는 수준으 로 증식하면 trypsin을 이용하여 세포를 분리하여 각 실 험을 위하여 12 well plate에 $1 \times 10^{5}$ cells/well로 나누었 다.

\section{저온상압플라즈마 장치}

세포 실험을 위한 헬륨가스를 이용하는 저온상압 플라 즈마 장치는 실험용 bench에 들어갈 수 있는 규격으로 맞춤 제작하였다(Feagle company, Yangsan, Korea) (Fig. 1). Power option은 +15 VDC - +24 VDC이고 warmup time은 1초이하, Input and Output signal은 $0-5$ $\mathrm{VDC}, 4$ - $20 \mathrm{~mA}$ 의 규격으로 전압 $4 \mathrm{~V}$, 전류 $4 \mathrm{~A}$ 로 설정
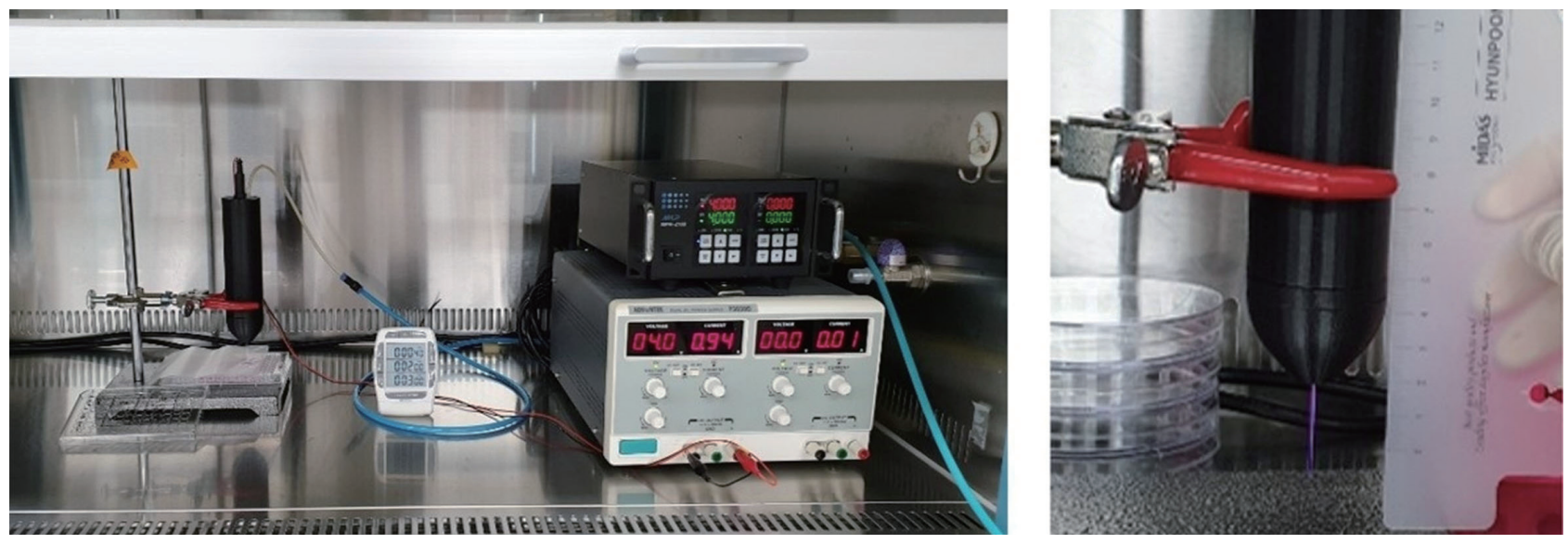

Fig. 1. Customized helium gas non-thermal atmospheric pressure plasma equipment for in vitro study. 
한 후 플레이트에서 $2 \mathrm{~cm}$ 떨어져서 세포에 1 분간 처리하 였다.

\section{세포 생존력 검사}

제작된 플라즈마 장치에서 조사되는 플라즈마의 세포 생존에 미치는 영향을 평가하기 위해 Cell Counting Kit8 (Dojindo Molecular Technologies, Rockville, USA)를 시행하였다. 96 well plate에 세포에 플라즈마 처리를 하 고 $37^{\circ} \mathrm{C}, 5 \% \mathrm{CO}_{2}$ 의 습기가 있는 세포배양기에서 각기 다른 배양 시간 (6시간과 24시간)으로 배양을 한다. 각 플레이트에 CCK-8 용액 $10 \mu \mathrm{L}$ 를 추가하고, 3시간 동안 다시 배양한다. 그 이후에 microplate reader (Molecular Devices, Sunnyvale, USA) $450 \mathrm{~nm}$ 의 흡광도에서 측정되 었다. 샘플은 4 개의 그룹으로 나누었고, 아무 처리도 하 지 않고 세포만 존재하는 Control군, 세포에 $1 \mu \mathrm{g} / \mathrm{mL}$ 의 Pg lipopolysaccharide (LPS) (InvivoGen, San Diego, $\mathrm{USA}$ ) 처리한 군, NTP를 처리한 군, Pg LPS와 NTP를 함께 처리한 군이다.

\section{염증성 사이토카인 분비 평가}

치주염 유발에 영향을 끼친다고 알려진 IL-8과 IL-6의 분비를 평가하였다. ${ }^{16,17}$ 샘플은 세포만 존재하는 Control 군, Pg LPS 처리군, NTP 처리군, Pg LPS와 NTP를 함께 처리한 군으로 인간치은섬유모세를 12 well plate에 $1 \times$ $10^{5}$ cells/well 로 위치시키고 $1 \mu \mathrm{g} / \mathrm{mL} \mathrm{Pg} \mathrm{LPS}$ 를 처리한 후 24시간 배양한 이후 NTP는 1분간 처리하였다. IL-8 와 IL-6 enzyme-linked immunosorbent assay (ELISA) kit (R\&D systems, Minneapolis, USA)를 이용하여 제조 사의 지시에 따라 분비양을 확인하였다. 각 샘플은 동일 한 조건으로 3 개씩 진행하였고, 각 실험은 3 번 반복하였 다.

\section{통계분석}

그룹간의 비교는 일원배치분산분석(One-Way ANOVA)을 통해 분석되었고, Tukey Honestly Significant Difference Test를 통해 사후 검정되었다. 유의 수준은 0.05 로 설정하였으며 통계분석은 SPSS 21.0버전(IBM SPSS Inc., Chicago, USA)을 이용하였다.

\section{결과}

인간치은섬유모세포 생존력 평가에서는 Pg LPS를 처 리한 군과 NTP를 처리한 군, Pg LPS와 NTP를 처리한 군 모두에서 생존율이 $92.28 \%$ 에서 $100 \%$ 사이로 존재하 고 통계적으로 유의성은 관찰되지 않았다. 6시간과 24 시간 세포배양시간에 따른 차이도 관찰되지 않았다(Fig. 2). 치주염 유발 염증성 사이토카인인 IL-8과 IL-6 분비 평가에서는 대조군 값을 기준으로 상대적 분비 정도를 분석한 결과, 세포에 Pg LPS를 처리한 군에서는 IL-8과 IL-6의 분비가 대조군보다 통계적으로 유의하게 증가 되었다. 그러나 NTP를 처리한 군에서는 Pg LPS를 처리 한 군보다 IL-8과 IL-6의 분비가 감소하였다. Pg LPS와 NTP를 함께 처리한 군에서는 NTP만 처리한 군 보다는 IL-8과 IL-6의 분비가 증가하였지만, Pg LPS만 처리한 군에 비해서는 통계적으로 유의하게 감소되었다(Fig. 3).

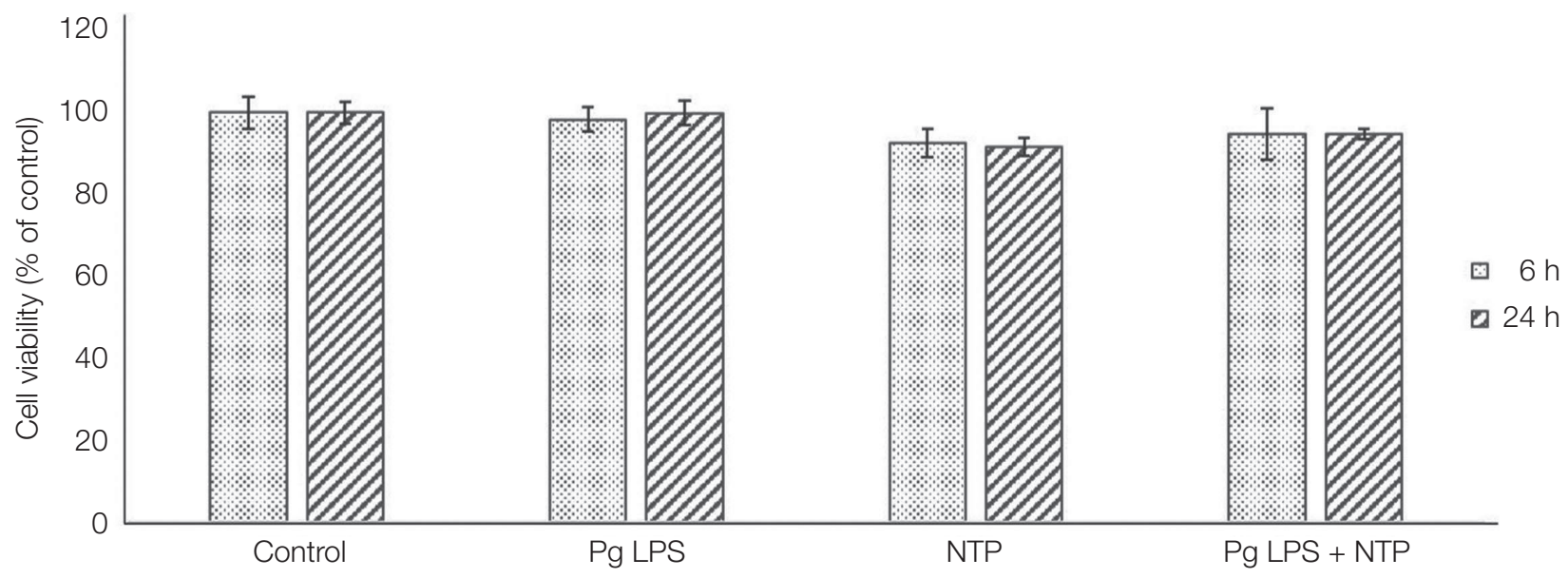

Fig. 2. Cell viability evaluation using CCK-8 kit.

Pg LPS: Porphyromonas gingivalis lipopolysaccharide, NTP: Nonthermal atmospheric pressure plasma. 
A

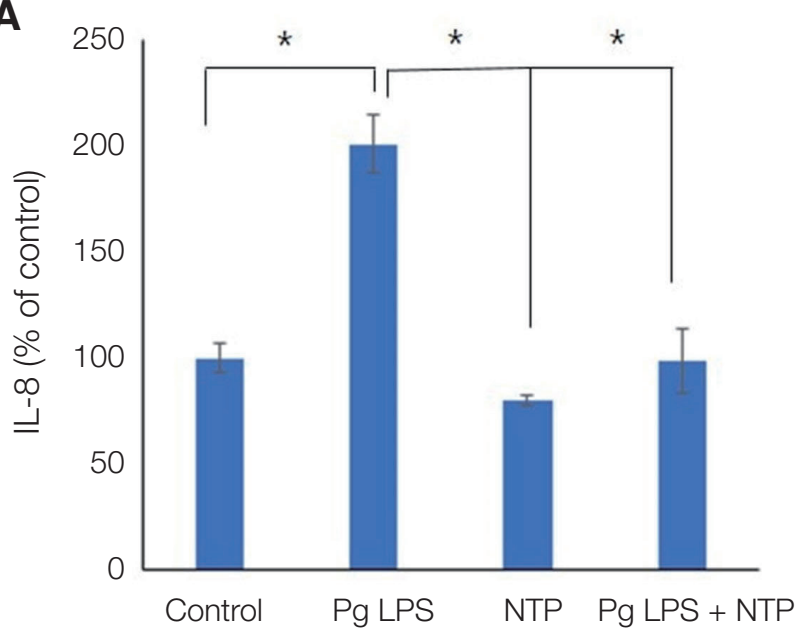

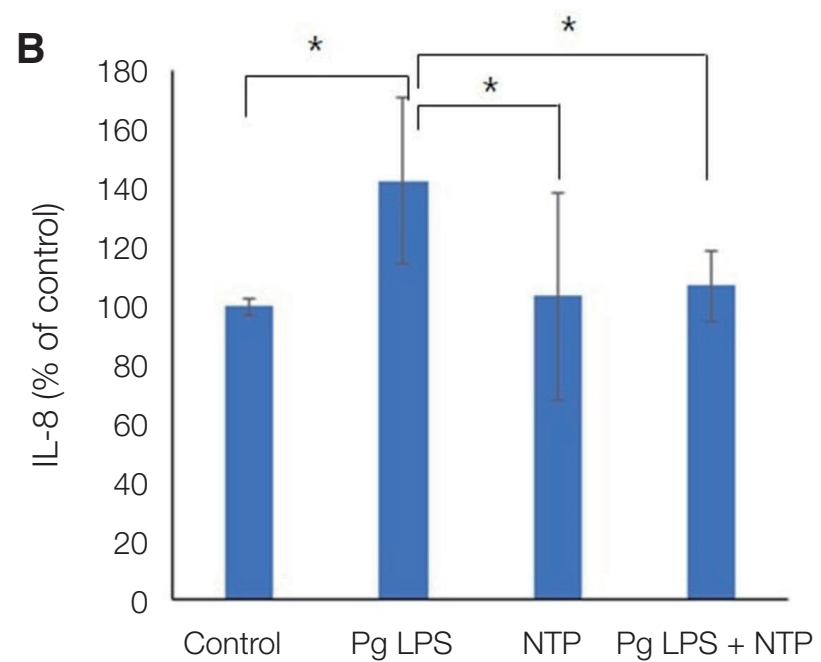

Fig. 3. Anti-inflammatory effect on human gingival fibroblast by helium gas nonthermal atmospheric pressure plasma (A) Interleukin-8 production, (B) Interleukin-6 production.

Pg LPS: Porphyromonas gingivalis lipopolysaccharide, NTP: Nonthermal atmospheric pressure plasma, IL-8: Interleukin-8, IL-6: Interleukin-6.

* statistically significant difference $(P<0.05)$.

\section{고찰}

본 연구는 치은에 대표적으로 존재하는 인간치은섬 유모세포에 Pg LPS를 처리하여 치주염을 유발시키고, NTP를 적용하여 치주염 유발과 관련되는 염증성 사이 토카인인 IL-8과 IL-6의 분비억제 효과를 확인해보았다. 그에 앞서 세포 생존율 검사를 시행하므로써 NTP가 인 간치은섬유모세포에 세포사멸을 유발시키는지도 함께 평가해보았다.

인체 조직에 적용하는 새로운 약물이나 임상기구가 개 발되기 위해서는 제일 먼저 해당 조직에 존재하는 세포 에 독성을 가지는지를 평가해야 하고 그것은 주로 세포 생존율 평가를 통해 확인할 수 있다. ${ }^{18,19}$ 본 연구에서는 NTP를 적용한 그룹과 다른 그룹간에 세포생존율의 통 계적으로 유의한 차이가 없음을 확인하므로써 NTP 장 치가 인간치은섬유모세포의 생존에 영향을 미치지 않음 을 확인할 수 있었다.

치주염은 세균성 집합체인 플라그에 의해 기시되는 만 성 염증성 질환으로, 플라그에 있는 세균과 그들의 부산 물들은 직접 또는 간접적으로 치주조직에 영향을 끼칠 수 있다. 직접적인 병리학적 효과는 부종이나 출혈과 같 은 염증반응을 유도하는 것이고, 간접적인 것은 숙주매 게 파괴과정을 유발하는 것이다. 치주염에서 치주조직의 파괴는 단핵구, 림프구, 섬유모세포 등의 활성을 통해 야
기된다. 게다가 세균의 LPS가 염증과정을 야기하는 사 이토카인의 분비를 자극하고 이들이 골과 조직의 분해를 야기하는 물질을 분비하게 하여 골과 세포외 기질을 파 괴시킨다. ${ }^{20}$ 본 연구에서는 치주염을 모사하는 세포 실험 을 진행하기 위하여 인간 치은조직에 많이 분포하며 치 주질환 발병시 면역과 염증 과정에 참여하는 섬유모세포 를 $^{21}$ 채득 후 배양하였고, 대표적 치주염 유발 세균인 $\mathrm{Pg}$ 균의 LPS를 세포에 처리하여 염증성 사이토카인인 IL-8 와 IL-6의 분비가 증가됨을 확인하였다. 인간 치은섬유 모세포에서 Pg LPS에 의해 IL-8가 분비되는 것은 잘 확 립된 치주염 모델로 알려져 있다. ${ }^{11}$

IL-8과 IL-6 레벨은 치주조직의 상태와 상관관계를 가 지고 치주염 발병에 기여하며 치주치료 이후 그 값이 반 응하는 것으로 알려져 있다. ${ }^{16,17} \mathrm{IL}-8$ 은 치은열구내 내피 세포, 치은섬유모세포, 호중구, 단핵구 그리고 식세포로 부터 유리될 수 있으며, 염증 지역에서 호중구의 강력한 화학 유인성 사이토카인 및 활성제이다. ${ }^{22} \mathrm{IL}-6$ 는 염증성 치주조직에서 기질금속단백분해효소의 분비를 증가시키 므로써 치주조직의 파괴를 야기할 수 있다. ${ }^{23}$

치주염의 진행을 억제하는 효과를 가지는 인자를 발견 하고 개발하기 위해 인간 치은섬유모세포에서 Pg LPS 자극을 통해 분비된 IL-8과 IL-6의 감소를 평가해 본 실 험들이 있다..$^{21,24,25}$ 본 연구에서는 NTP를 적용했을 때 IL-8과 IL-6의 분비가 유의하게 감소함을 확인하므로서, 
치주질환에서 NTP의 적용이 항염 효과를 가짐을 제안 할 수 있다. IL-8과 IL-6는 치주염 환자의 치주 조직과 치 은열구액 모두에서 많이 분비되는 염증성 매개체로서 이 들의 분비를 억제하는 것은 치주염의 개시와 진행을 제 한하는데 도움이 될 수 있다. ${ }^{26}$

최근에 인간치주인대세포에 NTP를 처리하여 tumor necrosis factor $\alpha$, IL-1 $\beta$, IL-6, IL-8 등의 발현을 확인하 므로서 치주조직의 상처치유에 NTP가 긍정적인 영향을 줄 수 있음을 in vitro study를 통하여 제안하였다. ${ }^{27}$ 또한 아르곤 가스를 이용한 NTP를 치주염동물 모델에 적용 한 논문이 최근에 게재되었다. ${ }^{28}$ 그러나 아직까지 치주염 의 발생기전에 NTP의 역할과 효능에 관한 세포실험은 제안되지 않았고, 치주염의 개시와 심도에서 염증반응이 질병의 심도를 결정하는데 중요한 역할을 한다고 알려 져 있으므로 세포실험을 통해 치주염 환경을 구축한 이 후 NTP를 적용하여 염증성 사이토카인 분비를 확인하 는 본 연구는 NTP의 치주염에 작용하는 기전에 대한 심 도있는 연구로 나아가기 위한 기초 자료가 될 수 있다.

염증을 조절하는 것은 치주염 치료에서 매우 중요한 요인이다. 천연물질을 이용하거나, 항생제를 저농도로 경구복용 하는 것과 같은 숙주조절요법을 제안하므로서 염증을 조절하려는 시도를 해왔다. ${ }^{25,29,30} \mathrm{NTP}$ 를 Pg LPS 를 처리한 인간섬유모세포에 적용하여 치주염 유발과 관 련된 염증성 사이토카인인 IL-8과 IL-6의 분비가 감소 됨을 확인하므로서, 치주염에서 NTP의 항염 효과 가능 성을 확인할 수 있었다. 다양한 염증성 사이토카인 분비 억제를 확인하는 세포 실험과 치주염 유발 동물 실험에 $\mathrm{NTP}$ 를 적용하는 후속 실험을 시행하여 NTP의 임상적 용 가능성까지 평가 해 볼 필요가 있다.

\section{결론}

NTP가 인간섬유모세포의 세포 생존율에 영향을 끼 치지 않고, 치주염 유발 염증성 사이토카인인인 IL-8과 IL-6의 분비를 억제하므로서 치주염 치료시 염증을 완화 시키는 도구로 활용할 수 있는 가능성을 제안한다.

\section{Acknowledgements}

이 논문은 부산대학교 기본연구지원사업(2년)에 의하 여 연구되었음.

\section{ORCID}

You li Park https://orcid.org/0000-0002-7753-863X

Hyun-Joo Kim https://orcid.org/0000-0001-7553-6289

Ju-Youn Lee https://orcid.org/0000-0002-0772-033X

Sung-Hee Jeong https://orcid.org/0000-0002-6296-4775

Eun-Young Kwon https://orcid.org/0000-0001-9555-0360

Ji-Young Joo https://orcid.org/0000-0002-4050-5797

\section{References}

1. Park SR, Hong JW, Lee HJ, Kim GC. Plasma Medicine; How can Nonthermal Atmospheric Plasma be Applied to Medicine? J Life Sc 2013;23:838-46.

2. Kim $\mathrm{CH}$. New conversing technology; plasma medicine. Korean J Otorhinolaryngol-Head Neck Surg 2010;53:593-602.

3. VON Woedtke T, Schmidt A, Bekeschus S, Wende K, Weltmann KD. Plasma Medicine: A Field of Applied Redox Biology. In Vivo 2019;33:1011-26.

4. Kim YM, Lee HY, Lee HJ, Kim JB, Kim S, Joo JY, Kim GC. Retention Improvement in Fluoride Application with Cold Atmospheric Plasma. J Dent Res 2018;97:179-83.

5. Nam SH, Lee HJ, Hong JW, Kim GC. Efficacy of nonthermal atmospheric pressure plasma for tooth bleaching. ScientificWorldJournal 2015;2015:581731.

6. Armand A, Khani M, Asnaashari M, AliAhmadi A, Shokri B. Comparison study of root canal disinfection by cold plasma jet and photodynamic therapy. Photodiagnosis Photodyn Ther 2019;26:327-33.

7. Pan J, Sun K, Liang Y, Sun P, Yang X, Wang J, Zhang J, Zhu W, Fang J, Becker KH. Cold plasma therapy of a tooth root canal infected with enterococcus faecalis biofilms in vitro. J Endod 2013;39:105-10.

8. Lee CM, Jeong YI, Kook MS, Kim BH. Combinatorial Effect of Cold Atmosphere Plasma (CAP) and the Anticancer Drug Cisplatin on Oral Squamous Cell Cancer Therapy. Int J Mol Sci 2020;21:7646.

9. Heitz-Mayfield LJ, Trombelli L, Heitz F, Needleman I, Moles D. A systematic review of the effect of surgical debridement vs non-surgical debridement for the treatment of chronic periodontitis. J Clin Periodontol 2002;29 Suppl 3:92-102.

10. Bartold PM, Van Dyke TE. Host modulation: con- 
trolling the inflammation to control the infection. Periodontol 2000 2017;75:317-29.

11. Schueller K, Hans J, Pfeiffer S, Walker J, Ley JP, Somoza V. Identification of Interleukin-8-Reducing Lead Compounds Based on SAR Studies on Dihydrochalcone-Related Compounds in Human Gingival Fibroblasts (HGF-1 cells) In Vitro. Molecules 2020;25:1382.

12. Eaton KA, Kaiser JB, Davies RM. The removal of root surface deposits. J Clin Periodontol 1985;12: 141-52.

13. Cobb CM. Lasers and the treatment of periodontitis: the essence and the noise. Periodontol 2000 2017;75:205-95.

14. Park EJ, Kwon EY, Kim HJ, Lee JY, Choi J, Joo JY. Clinical and microbiological effects of the supplementary use of an erythritol powder air-polishing device in non-surgical periodontal therapy: a randomized clinical trial. J Periodontal Implant Sci 2018;48:295-304.

15. Mahasneh A, Darby M, Tolle SL, Hynes W, Laroussi M, Karakas E. Inactivation of Porphyromonas gingivalis by low-temperature atmospheric pressure plasma. Plasma Med 2011;1:191-204.

16. Shimada Y, Komatsu Y, Ikezawa-Suzuki I, Tai H, Sugita N, Yoshie H. The effect of periodontal treatment on serum leptin, interleukin-6, and Creactive protein. J Periodontol 2010;81:1118-23.

17. Lagdive SS, Marawar PP, Byakod G, Lagdive SB. Evaluation and comparison of interleukin-8 (IL-8) level in gingival crevicular fluid in health and severity of periodontal disease: a clinico-biochemical study. Indian J Dent Res 2013;24:188-92.

18. Begley CG, Ellis LM. Drug development: Raise standards for preclinical cancer research. Nature 2012;28:531-3.

19. Wei M, Zhang R, Zhang F, Zhang Y, Li G, Miao R, Shao S. An Evaluation Approach of Cell Viability Based on Cell Detachment Assay in a Single-Channel Integrated Microfluidic Chip. ACS Sens 2019;4: 2654-61.

20. Hegde R, Awan KH. Effects of periodontal disease on systemic health. Dis Mon 2019;65:185-92.

21. Takashiba S, Naruishi K, Murayama Y. Perspective of cytokine regulation for periodontal treatment:
Fibroblast biology. J Periodontol 2003;74:103-10.

22. Finoti LS, Nepomuceno R, Pigossi SC, Corbi SC, Secolin R, Scarel-Caminaga RM. Association between interleukin-8 levels and chronic periodontal disease: A PRISMA-compliant systematic review and meta-analysis. Medicine (Baltimore) 2017;96:e6932.

23. Naruishi K, Nagata T. Biological effects of interleukin-6 on Gingival Fibroblasts: Cytokine regulation in periodontitis. J Cell Physiol 2018;233:6393400.

24. Shindo S, Hosokawa Y, Hosokawa I, Shiba H. Interleukin (IL)-35 Suppresses IL-6 and IL-8 Production in IL-17A-Stimulated Human Periodontal Ligament Cells. Inflammation 2019;42:835-40.

25. Xiong G, Ji W, Wang F, Zhang F, Xue R, Cheng M, Sun Y, Wang X, Zhang T. Quercetin Inhibits Inflammatory Response Induced by LPS from Porphyromonas gingivalis in Human Gingival Fibroblasts via Suppressing NF- $x$ B Signaling Pathway. Biomed Res Int 2019;2019:6282635.

26. Muniz FW, Nogueira SB, Mendes FL, Rösing CK, Moreira MM, de Andrade GM, de Sousa Carvalho $\mathrm{R}$. The impact of antioxidant agents complimentary to periodontal therapy on oxidative stress and periodontal outcomes: A systematic review. Arch Oral Biol 2015;60:1203-14.

27. Kleineidam B, Nokhbehsaim M, Deschner J, Wahl G. Effect of cold plasma on periodontal wound healingan in vitro study. Clin Oral Investig 2019;23:1941-50.

28. Zhang Y, Xiong Y, Xie P, Ao X, Zheng Z, Dong X, Li H, Yu Q, Zhu Z, Chen M, Chen W. Non-thermal plasma reduces periodontitis-induced alveolar bone loss in rats. Biochem Biophys Res Commun 2018;503:2040-6.

29. Soares DJ, Walker J, Pignitter M, Walker JM, Imboeck JM, Ehrnhoefer-Ressler MM, Brasil IM, Somoza V. Pitanga (Eugenia uniflora L.) fruit juice and two major constituents thereof exhibit antiinflammatory properties in human gingival and oral gum epithelial cells. Food Funct 2014;5:2981-8.

30. Hajishengallis G, Chavakis T, Lambris JD. Current understanding of periodontal disease pathogenesis and targets for host-modulation therapy. Periodontol 2000 2020;84:14-34. 


\section{치주염 치료를 위한 저온상압 플라즈마의 항염효과 : 예비 실험}

박유리 ${ }^{1}$ 전공의, 김현주 ${ }^{1}$ 조교수, 이주연 ${ }^{1}$ 교수, 정성희 ${ }^{2}$ 교수, 권은영 ${ }^{3}$ 임상부교수, 주지영 ${ }^{1 *}$ 부교수

${ }^{1}$ 부산대학교 치의학전문대학원 치주과학교실

${ }^{2}$ 부산대학교 치의학전문대학원 구강내과학교실

${ }^{3}$ 부산대학교병원 치과진료센터

목적: 대표적인 만성 구강내 염증성 질환인 치주염의 치료에 저온상압 플라즈마의 적용 가능성을 평가해 보고자, 치주 조직내 많이 분포하고 있는 치은섬유모세포에 대한 항염효과를 평가해보았다.

연구 재료 및 방법: 두명의 환자의 구강내에서 건강한 치은조직을 채득하여 primary culture 시행한 후 실험실에서 치은섬 유모세포를 계대배양하였다. 세포 실험을 위해 헬륨 가스를 이용하는 저온상압 플라즈마 장치를 제작하였다. 치주염증 을 유도하기 위해 Porphyromonas gingivalis (Pg)의 LPS를 처리하고, CCK-8 kit를 통해 세포생존율 평가를 시행하고 염증성 사이토카인인 interleukin (IL)-8, IL-6의 분비정도를 평가하였다.

결과: 인간치은섬유모세포 생존율 평가에서는 Pg LPS를 처리한 군과 플라즈마를 처리한 군, Pg LPS와 플라즈마를 함께 처리한 군 모두에서 생존율이 $92.28 \%$ 에서 $100 \%$ 사이로 존재하고 통계적으로 유의성은 관찰되지 않았다. 6 시간과 24시 간 세포배양시간에 따른 세포생존율 차이도 관찰되지 않았다. Pg LPS를 적용하였을 때 대조군에 비해 IL-8과 6의 분비 가 증가되었으며, 저온상압 플라즈마의 적용시 그 분비가 통계적으로 유의하게 감소되었다.

결론: 저온상압 플라즈마가 인간섬유모세포의 세포 생존율에 유의한 영향을 끼치지 않았고, 치주염유발 염증성 사이토 카인인인 IL-8과 IL-6의 분비를 억제하였다.

(구강회복응용과학지 2021;37(2):88-94)

주요어: 치주염; 저온상압플라즈마; 예비실험; 항염효과, 인간치은섬유모세포

*교신저자: 주지영

(50612)경상남도 양산시 물금읍 범어리 금오로 20 , 부산대학교 치의학전문대학원 치주과학교실, 치의학연구소

Tel: 055-360-5203 | Fax: 05-360-5194 | E-mail: joojy@pusan.ac.kr

접수일: 2021년 3월 11일 | 수정일: 2021년 4월 6일 | 채택일: 2021년 5월 21일 